\title{
Will the changes proposed to the conceptual framework's definitions and recognition criteria provide a better basis for IASB standard setting?
}

\section{Arjan Brouwer, Martin Hoogendoorn \& Ewout Naarding}

To cite this article: Arjan Brouwer, Martin Hoogendoorn \& Ewout Naarding (2015) Will the changes proposed to the conceptual framework's definitions and recognition criteria provide a better basis for IASB standard setting?, Accounting and Business Research, 45:5, 547-571, DOI: 10.1080/00014788.2015.1048769

To link to this article: https://doi.org/10.1080/00014788.2015.1048769

Published online: 03 Aug 2015.

Submit your article to this journal $₫$

Џ Article views: 3471

Q View related articles ¿

View Crossmark data

Citing articles: 12 View citing articles $\widetilde{ }$ 


\title{
Will the changes proposed to the conceptual framework's definitions and recognition criteria provide a better basis for IASB standard setting?
}

\author{
ARJAN BROUWER ${ }^{\mathrm{a} *}$, MARTIN HOOGENDOORN $^{\mathrm{b}}$ and \\ EWOUT NAARDING
}

\author{
${ }^{a}$ Amsterdam Business School, University of Amsterdam, Amsterdam, the Netherlands; ${ }^{b}$ Erasmus School \\ of Economics, Erasmus University Rotterdam, Rotterdam, the Netherlands; ${ }^{c}$ Center for Financial \\ Accounting \& Reporting, Nyenrode Business Universiteit, Breukelen, the Netherlands
}

\begin{abstract}
In this paper we evaluate the International Accounting Standards Board's (IASB) efforts, in a discussion paper (DP) of 2013, to develop a new conceptual framework (CF) in the light of its stated ambition to establish a robust and consistent basis for future standard setting, thereby guiding standard setting decisions in complex and controversial areas. We investigate the impact of the definitions and recognition criteria for assets and liabilities in the existing CF and the DP. We conclude that, in areas where standards have diverged from the CF in the past, that is, not consistently applying probability thresholds, the DP supports the existing standards by removing those thresholds. Furthermore, the DP includes the more judgemental criteria of relevance and faithful representation to determine whether an item should be recognised as an asset or liability. This would justify those existing standards which currently do not recognise items that meet the (current and revised) definitions of asset or liability. Altogether, we conclude that the development of IFRSs will continue to be the outcome of professional debate, negotiation, consensus seeking and political influence. We therefore recommend that additional measures should be taken by the IASB to ensure coherence in the development and application of standards after implementation of a new CF.
\end{abstract}

Keywords: conceptual framework; balance sheet approach; assets; liabilities; IFRS

JEL Classification: M41

\section{Introduction}

The conceptual framework $(\mathrm{CF})$ is intended to be a coherent conceptual basis for the International Accounting Standards Board (IASB 2013a) in developing accounting standards, and the new

\footnotetext{
*Corresponding author. Emails: a.j.brouwer@uva.nl, arjan.brouwer@nl.pwc.com
} 
definitions and recognition criteria for assets and liabilities as proposed in the discussion paper (DP) are designed to provide clearer guidance to solve issues in areas such as leases, rate-regulated activities and non-financial liabilities (IASB 2012). In this paper, we analyse the IASB's application of the existing CF and current efforts to develop a new CF as reflected in the DP in the light of this ambition. Specifically, we analyse how and to what extent the IASB has applied the definitions and recognition criteria of the existing $\mathrm{CF}$ as the basis for standard setting decisions in the past and whether the changes to those definitions and recognition criteria as proposed in the DP are likely to enhance the CF's role as an sound basis for the future development of consistent accounting standards based on newly developed concepts.

In the DP, the IASB continues to focus on the statement of financial position (hereafter, for simplicity, 'balance sheet'). ${ }^{1}$ That is, the definition, recognition and measurement of assets and liabilities are given primacy in the IASB's standard setting. Income and expenses derive from this. Although this approach has been criticised (e.g. see Dichev 2008), the DP indicates that the IASB intends to continue to apply it. Therefore, the robustness, understandability and consistent application of these asset/liability definitions and principles are crucial.

However, an analysis of standard setting shows that the IASB and its Interpretations Committee (IFRS IC) have struggled to fit their intended outcomes into the existing definitions and criteria. In its abandoned exposure draft (ED) aimed at the revision of IAS 37 Provisions, Contingent Liabilities and Contingent Assets, the IASB proposed to remove the probability threshold, meaning that a provision would have been recognised when (1) the entity had a present obligation and (2) a reliable estimate could be made of the amount of the obligation. ${ }^{2}$ The ED proposed not to include a probable outflow threshold but that uncertainty about the amount and timing of outflows should be reflected in the liability's measurement at its expected value. The removal of a probability threshold would not be in line with the existing $\mathrm{CF}$, and many respondents expressed concerns about this proposal. The project was put on hold in 2010, but only after the IASB published a Staff Paper (IASB 2010b) stating that it intented to make the same probability assessment as required under current IAS 37 part of the assessment to determine whether an obligation actually exists, that is, part of existence uncertainty instead of outcome uncertainty. However, this was not clear from the initial proposals. In the project on Leases, the IASB had to significantly change its view on what constitutes a liability under the CF between the initial proposals and its revised ED, which appeared in $2013 .^{3}$

The application of the definitions to regulatory assets and liabilities, complex financial instruments and non-financial liabilities also continues to raise questions and trigger debate. This is apparent, for instance, in questions taken to the IFRS IC, where the issue of regulatory assets and liabilities has been brought forward twice (issues IAS 37-3 and IAS 38-1) and where the matter of economic compulsion and substance (e.g. see issue IAS 32-2) as well as other questions on the application of IAS 32 Financial Instruments: Presentation have been raised ${ }^{4}$. For rateregulated activities, after having published an ED in 2009, the IASB has not yet been able to develop a standard to identify when an asset or a liability exists resulting from rate regulation. It has therefore decided to develop an interim standard, that allows new IFRS adopters to continue applying their local GAAP for this aspect when certain criteria are met, while it works on a permanent solution. Debate about the classification of financial instruments as debt or equity resulted in the inclusion of an exception in IAS 32 for puttable financial instruments as well as the release in 2008 of a DP, Financial Instruments with Characteristics of Equity, which explores alternative approaches to the distinction between debt and equity. The IFRS IC issued IFRIC 21 on Levies in 2013 and concluded that economic compulsion and the going concern assumption do not justify recognition, under IAS 37, of liabilities triggered by operating in a future period (IFRS IC 2013).

We analyse whether changes to the definitions and recognition criteria as proposed in the DP are likely to enhance the CF's role as a sound basis for the future development of consistent 
accounting standards based on newly developed concepts. In Section 2, we discuss general academic literature about the existing CF and difficulties with its application as well as literature that focuses on the intentions that a standard setter may have with the development of a CF. In Section 3 , we analyse in detail how the current definitions and recognition criteria for assets and liabilities have been applied by the IASB in developing accounting standards, and how this has been evaluated in academic literature. The insights from this analysis are important for understanding how the IASB uses the CF in its standard setting activities and for placing the DP's proposals in the context of the possible intentions that the IASB, according to the literature, could have for its new CF. In Section 4, we analyse how the revised definitions might affect standard setting. We investigate how existing standards would be affected if the IASB were to align existing standards with the DP and whether the revised definitions have the potential to solve ongoing discussions in controversial areas. This is designed to place the IASB's efforts in the context of its ambition to provide clearer guidance for solving existing and potential future issues relating to the recognition of assets and liabilities (IASB 2012). In Section 5, we present our conclusions and recommendations.

The DP was a first step in the process of developing a new CF, whereby the IASB explicitly sought external input (DP para. 1.13). As a result of this input, including our analysis, the IASB may further develop its views, and the new CF will likely differ from the initial views expressed in the DP.

\section{The role and function of the $\mathbf{C F}$}

According to the CF, its purpose is to assist the IASB in the development of future IFRSs, in reviewing existing IFRSs and in the promotion of harmonisation. Furthermore, the CF should assist national standard setters, preparers, auditors and users in applying IFRS and in interpreting financial statements that are prepared based on IFRS. IAS 8 Accounting Policies, Changes in Accounting Estimates and Errors (para. 11) furthermore requires preparers to consider the CF's definitions, recognition criteria and measurement concepts for assets, liabilities, income and expenses when developing and applying an accounting policy in the absence of an IFRS that specifically applies to a transaction, event or condition.

The IASB has however experienced difficulties in applying its CF in the development of IFRSs that have been documented in the academic literature. Booth (2003) identifies how inconsistencies in the current CF have led to inconsistent accounting standards, while Newberry (2003, p. 325) asks "how "conceptually robust" accounting standards [can] be derived from an incoherent framework'. According to Bradbury (2003), the CF has inadequately dealt with complex financial instruments, resulting in significant deviations from the $\mathrm{CF}$ in standard setting. Barker and McGeachin (2013) believe that inconsistencies in the reporting of assets and liabilities arise because the IASB does not distinguish between measurement (observable measures) and estimation. McGregor and Street (2007) state that the IASB has to deal with issues in the context of an outdated CF that does not reflect current thinking owing to a failure to regularly revisit the CF. These and similar complaints about the current basis for the IASB's standard setting have resulted in a call to the IASB to give priority to the development of an updated CF (Jones and Wolnizer 2003, Whittington 2008; respondents to the IASB's 2011 Agenda Consultation IASB 2012). The DP is a step towards achieving this: 'the primary purpose of the revised Conceptual Framework is to assist the IASB by identifying concepts that it will use consistently when developing and revising IFRSs' (DP para. 1.26). According to Solomons (1986), a good CF will help in economising efforts and in gaining consistency, will improve communication and will be a defence against politicisation.

This function of the CF is also discussed by Walker (2003), who suggests that the CF can assist the IASB in identifying existing standards that are inconsistent with the concepts, in 
improving or developing standards, and can provide a guide to practitioners in case of new situations not dealt with in existing standards. Others are more sceptical about the role of the $\mathrm{CF}$ as a solid basis for future standard setting. According to Peasnell (1982), in a situation where a standard setter is dependent on the goodwill of companies, regulators and others (in the IASB's case, politicians) to embrace and support its standards, it needs flexibility to negotiate as part of its standard setting process. According to Gerboth (1987), a CF cannot and should not avoid or foreclose relevant debate among professionals about what is proper accounting for specific situations and transactions by agreeing on abstract principles in advance. Rather than a technical or functional role, Hines $(1989,1991)$ and Peasnell $(1982)$ see the development of a CF as a strategic, political step that creates the appearance of a coherent basis for standard setting aimed at gaining credibility and legitimacy.

Walker (2003) also notes that the CF development process can be aimed at legitimising existing standards. Newberry (2003) believes that a coherent up-to-date CF and accounting standards that are developed consistently with it, should not be expected, given the continuously changing reporting environment and political influence. She holds that the IASB uses bits and pieces from an incoherent CF to justify individual standard setting decisions, and that the IASB does not necessarily strive for coherence and consistency. According to Dean and Clarke (2003), previous efforts to develop a CF by other standard setters have focused on explaining existing practice rather than on developing concepts to which new standards should conform. O'Brien (2009) is of the opinion that the first phase of developing a new CF by the IASB (objectives and qualitative characteristics) was aimed at eliminating concepts such as stewardship and reliability that did not support the direction that the Board had already taken in standard setting.

According to the DP (para. 1.12), 'the IASB's aim is to select concepts that will result in financial statements that meet the objective of financial reporting, not to justify existing requirements and practice'. This is in line with the objective that Jones and Wolnizer (2003), Whittington (2008) and others see for it. However, the UK's Financial Reporting Council (FRC 2014, p. 3) does not seem to be convinced that the IASB is delivering on its promise: 'Principles should not be discarded or diluted merely because they are inconsistent with standards: still less should the Conceptual Framework be 'reverse engineered' to provide a rationalisation for existing standards'.

In the following sections, we analyse the IASB's efforts in the DP in light of the ambition to develop a sound basis that will help to solve important issues that the IASB currently faces during the standard setting process. In order to assess the IASB's proposals against its ambitions, it is important to understand how the IASB has applied the existing CF in developing standards in the past and to place the concepts proposed in the DP in context of the existing standards and inconsistencies that have arisen when these standards were developed. This will also provide a contrast with the more sceptical view that the DP may only be a strategic, political step aimed at legitimising existing standards (e.g. Peasnell 1982, Hines 1989, 1991, Dean and Clarke 2003, Walker 2003, O’Brien 2009).

\section{The current CF and its impact on the recognition of assets and liabilities in standard setting}

Under the current CF, an asset is defined as a 'resource controlled by the entity as a result of past events and from which future economic benefits are expected to flow to the entity' and a liability as 'a present obligation of the entity arising from past events, the settlement of which is expected to result in an outflow from the entity of resources embodying economic benefits' (IASB 2010c, para. 4.4). However, an asset or a liability is only recognised when the inflow or outflow of benefits is probable. According to Hellman (2008), the probability threshold for assets is a 
reflection of prudence. Prudence had been included as a qualitative characteristic in the $1989 \mathrm{CF}$ (para. 37), although the CF warned against excessive prudence. However, prudence was removed from the $\mathrm{CF}$ as revised in 2010 because it conflicts with neutrality (Basis for conclusions, BC 3.27). Nevertheless, the parts of the CF dealing with the recognition criteria have not yet been amended and the probability thresholds for assets and liabilities were thus retained.

According to the current CF para. 4.7 (IASB 2010c), the definitions of assets and liabilities (as well as equity) underlie the review of existing standards and the development of new standards. Income and expenses follow from the definitions of assets and liabilities, and para. 4.50 stresses that the application of the matching concept in relation to expenses does not allow for the recognition of items in the balance sheet that do not meet the definition of assets or liabilities.

In this section, we analyse how the IASB has translated the current CF's definitions and recognition criteria into existing IFRSs on assets and liabilities. We assess various standards, consider the assets and liabilities that are recognised based on those standards in light of the current $\mathrm{CF}$ definitions and recognition criteria and take into account relevant academic literature.

\subsection{Tangible assets (IAS 16, IAS 17, IAS 40)}

According to IAS 16 Property, Plant and Equipment (para. 7), the cost of an item of property, plant and equipment (PPE) shall be recognised as an asset if and only if it is probable that future economic benefits associated with the item will flow to the entity. In relation to PPE, the IASB has thus applied the CF definitions and recognition criteria in standard setting. However, assets that are acquired under lease contracts are often not recognised. Under IAS 17 Leases, some leased assets (finance leases) are accounted for as assets, but the majority of leases are classified as operating leases and not accounted for on the balance sheet, although IAS 40 Investment Property (para. 6) allows for recognition of investment property leased under an operating lease, under the condition that it is measured at fair value. The CF does not support the distinctions made between various leases in IAS 17 and IAS 40. The IASB (2009) has also concluded that leased assets meet all the elements of the definition and recognition of an asset in the CF: as a result of a past event, the lessee controls (the right to use) the asset, and economic benefits are expected to flow from the use of the asset and are probable. The IASB thus concluded that not recognising assets leased under operating leases is not in accordance with the CF. This view is shared by Booth (2003), who states that a lessee acquires control over the leased asset even though it does not acquire legal ownership and that, since (legal) ownership is not part of the definition of an asset, a leased asset meets the definition of an asset for the lessee.

\subsection{Intangible assets (IAS 38, IFRS 3)}

According to IAS 38 Intangible Assets (para. 21), intangible assets are only recognised if it is probable that the expected future economic benefits that are attributable to the asset will flow to the entity. The general requirement in IAS 38 is thus similar to the requirement for PPE in IAS 16 and the CF. However, in the remainder of the standard, and related requirements in IFRS 3 Business Combinations, various requirements are included that may result in the recognition of intangible assets that do not meet the CF definitions and recognition criteria as well as the exclusion of intangible assets that do meet the definition of an asset. First, recognition of internally generated intangible assets is generally not allowed by IAS 38 . The standard (paras 54 and 63) explicitly forbids recognition as an asset of internally generated goodwill, research, brand names, customer lists and similar items. The only internally generated intangible asset that can be capitalised is one that arises from an internal development project, but only when various criteria are met - which in practice often results in capitalisation of only a limited portion 
of an entity's expenditure on development. Furthermore, capitalisation is limited to the expenditures incurred as of the date that the capitalisation criteria are met, which means that even when the capitalisation criteria are met (para. 57), the intangible asset is not recognised at its cost but only at a portion of its cost (para. 71). Some agree with the IASB's decision to preclude many intangible assets from capitalisation. According to Penman (2009), intangible assets that are not legal rights (e.g. unlike patents) are not specific enough to have an observable value attached to them, and therefore recognition would result in speculative values on the balance sheet, which do not provide informational value to analysts. Walker and Oliver (2005) are of the opinion that capitalising software development costs does not result in reliable information, and recommend that expenditures on software development should be expensed as incurred.

However, the lack of recognising many intangible assets on the balance sheet has also been criticised (Penman 2009). Lev (2003) holds that on-balance sheet presentation is required to solve the issue of partial, inconsistent and confusing information about these important assets, while Eckstein (2004) concludes that the objective of providing relevant information mandates the recognition of intangible assets. Many studies present evidence that intangible asset values are relevant for investor decision-making. Research includes that by Lev and Sougiannis (1996) on estimated R\&D assets, Aboody and Lev (1998) and Mohd (2005) on capitalised software development costs, Kallapur and Kwan (2004) on recognised brand values, and Barth et al. (1998) on estimated brand values. Furthermore, Wyatt (2005) concludes that management decision-making about the recogntion of intangible assets reflects their insights in the underlying economics of the entity. It is therefore concluded that, even though reliability may be a concern, recognised amounts are reliable enough to be relevant, and that not recognising a wide range of intangible assets eliminates relevant information from the financial statements.

Thus, IAS 38 prohibits recognition of internally generated intangible assets that do meet the definition of an asset and for which the academic literature shows that their values are relevant for decision-making. At the same time, IFRSs require on-balance sheet recognition of the same type of items when they are acquired, even if they do not meet the CF's definition or recognition criteria of an asset. According to IAS 38 and IFRS 3, intangible assets acquired separately or in a business combination must always be recognised as separate assets, and no separate assessment is made about whether future economic benefits are probable. Probability is reflected in measurement since the price that an entity pays to acquire the asset is assumed to reflect expectations about the probability of future inflows of economic benefits. This may result in intangible assets being recognised for which it is not probable that future economic benefits will flow to the entity. An example is the acquisition of early-stage in-process research and development (IPR\&D) directly or as part of a business combination in the pharmaceutical industry. While generally no assets are recognised for IPR\&D projects carried out inside a pharmaceutical company, given the low probability of success, such assets would be recognised for acquired IPR\&D including early-stage items. Similarly, goodwill, brand names, customer lists and similar items are not recognised when internally generated, but are recognised when they are acquired. Such a difference in accounting treatment for internally developed intangible assets and acquired intangible assets is not based on the CF. Bloom (2009) holds that there is no difference between internally generated goodwill and acquired goodwill, except that there are more practical difficulties with recognition of internally generated goodwill on balance than recognition of acquired goodwill, and double entry bookkeeping justifies capitalisation of acquired goodwill, but not internally generated goodwill. Furthermore, since acquired goodwill is not amortised under IFRS, it is gradually replaced by internally generated goodwill over time.

Whether acquired goodwill meets the definition of an asset under the CF is an open question and subject to debate. In the Basis for Conclusions on IFRS 3, the IASB concludes that goodwill 
meets the definition of an asset even though goodwill partially consists of items that are not controlled by the entity, such as a well-trained workforce and loyal customers (IFRS 3, BC 323). Cortese-Danile and Gornik-Tomaszewinski (2002) are of the view that, on this topic under US GAAP, the FASB made a sophisticated argument that goodwill meets the definition of an asset and meets the criteria of relevance and reliability. However, Booth (2003) is explicit in his view that goodwill is not controlled by the entity and does not meet the definition of an asset. Although future economic benefits may be expected, goodwill consists of unidentified items and not of rights that are controlled by the entity. Ma and Hopkins (1988) go even further in stating that, if anything, there may be arguments for recognising internally generated goodwill, because it relates to the earnings capacity of the entity's existing assets, but not for acquired goodwill, since acquired goodwill relates to synergies that must be realised after the business combination has been completed and are not present in the acquiree's existing operations at the acquisition date. Goodwill is linked to the other assets acquired in a business combination rather than being a standalone asset that meets the definition of an asset in the CF. One might argue that the capitalisation of goodwill results in the initial recognition of the acquired business, or subsidiary, at cost. This may be true from a separate financial statements perspective, whereby goodwill is part of the cost of the subsidiary and is thereby captured in the cost of an identifiable and separately recognisable asset. Similarly, in the separate financial statements, internally generated goodwill can be recognised on the balance sheet as part of the value of the subsidiary, because subsidiaries can be valued at fair value in the separate financial statements (IAS 27 Separate Financial Statements, para.10). However, this is not relevant for the application of the CF definitions and recognition criteria in the consolidated financial statements. According to the CF, in the consolidated financial statements, expenditure on an item that does not meet the definition of an asset should be expensed (CF 2010, para. 4.52).

The best arguments for recognising acquired - not internally generated - goodwill as an asset in the consolidated financial statements under IFRS seem to be convenience and avoidance of an unidentified difference in the double entry bookkeeping system that would significantly affect the income statement if not capitalised. Goodwill paid in acquisitions can involve significant amounts related to individual transactions which are of a non-recurring nature. Capitalising this avoids earnings volatility as a result of acquisitions until a goodwill impairment is recognised in a future year. Recognising expenditures on the internal generation of goodwill and various other intangible assets as an expense in the income statement does not result in earnings volatility, because the expenditure is incurred over time instead of at once. The predictability, manageability and stability of these expenses over time also make immediate expensing more acceptable for entities than immediate expensing of goodwill paid in acquisitions. As such, recognised goodwill from acquisitions has the nature of a deferred cost rather than that of an asset by itself, capturing the amount that is paid for anything other than identifiable assets that meet the CF recognition criteria.

\subsection{Financial assets (IAS 28, IAS 32, IAS 39, IFRS 10, IAS 18)}

For financial assets, no recognition threshold is defined in IFRS. All financial assets are recognised (initially) at fair value, which generally equals cost, plus - in certain cases - transaction costs when the entity becomes part of the contract or acquires its interest in an associate or joint venture. Probabilities of inflows are reflected in the price that the buyer and seller agree or the fair value that is calculated. This inconsistency between IAS 39 Financial Instruments: Recognition and Measurement and the CF has also been identified by Bradbury (2003), who holds that the discussions about the accounting for financial instruments show that the CF needs significant modification. 
As a result, financial assets may be recognised even though inflows from the asset are not probable. An entity may, for instance, acquire an out-of-the-money option (derivative) to buy an interest in a non-listed company. The option has a $20 \%$ chance of becoming in-the-money before maturity and cannot be sold to another party. Such an option will have a positive fair value and should be recognised at fair value under current IAS 39, whereas it does not meet the requirement of probable future inflows. For derecognition of financial assets, IAS 39 moves to a risks and rewards model and, depending on the situation, substantially all risks and rewards must have been transferred before a financial asset is derecognised. The difference between the recognition and derecognition criteria means that one entity may recognise an asset for a particular set of contractual rights and obligations whereas another entity does not, simply because it arrived at the (exactly equal) situation via a different route. The economic position of an entity that has sold the right to the cash flows from its receivables but retains the collectability risk is, for instance, similar to the economic position of an insurance company that has absorbed the collectability risk of another entity's receivables. However, under current IFRS, the first entity will not derecognise its receivables, because it has not transferred the risks and rewards, whereas the insurance company will not recognise the receivables of all entities to which it has provided an insurance for the collectability risk. The difference is caused by the fact that the recognition criteria for financial instruments do not mirror the derecognition criteria.

IFRS 10 Consolidated Financial Statements requires recognition of contingent consideration to be received for a business that is disposed of at fair value even if the inflow is not probable. However, IAS 18 Revenue only allows recognition of a receivable for products or services sold when the inflow is probable and some other criteria are met, effectively setting the hurdle at a higher than probable level. For its new revenue recognition standard, the IASB initially proposed not to have extra probability criteria, but then introduced them in relation to collectability and variable consideration in $2013^{5}$ and retained them in IFRS 15 Revenue from Contracts with Customers (IASB 2014b, paras 9 and 56).

\subsection{Inventories (IAS 2)}

IAS 2 Inventories does not specifically include a probability threshold for the recognition of inventory as an asset. Given the definition of inventory, items that are held for sale or in the process of production, and the requirement to value inventory not higher than net realisable value, this will - however - not be likely to result in items recognised as assets if an inflow of future economic benefits is not probable.

\subsection{Financial liabilities (IAS 17, IAS 32, IAS 39, IFRS 3)}

According to IAS 32 and IAS 39, a liability must be recognised for all financial instruments for which the entity may be required to settle its obligation in cash or another financial asset. Similarly to financial assets, IAS 39 does not apply a recognition threshold and that may, for instance, result in the recognition of liabilities for out-of-the money derivatives for which an outflow of economic benefits to settle them in the future is not probable, but which nevertheless have a fair value. According to Barker and McGeachin (2013), this is in conflict with the CF. Furthermore, IFRS 3 requires the recognition of liabilities for contingent consideration at fair value irrespective of the probability of a future outflow of economic benefits.

Instruments for which the entity can avoid settlement do not result in the recognition of a liability. As confirmed by the IFRS Interpretations Committee, economic compulsion is not taken into account when assessing whether a liability exists. ${ }^{6}$ As a result, many instruments for which future cash outflows from the entity are expected by both the entity and the holder are not recorded as 
liabilities, because the payment is avoidable. Examples include ordinary shares for which dividends may be expected under the stated dividend policy but not required, and various types of (hybrid) bonds on which interest is only payable when dividends are paid and for which the payment of interest may or may not be incentivised via contractual terms. As discussed by Beaver (1991) and Murray (2010), a complexity in the discussion on the recognition of liabilities is that, in many cases, a mix of past and future events affects the final settlement of an entity's liabilities. First, a liability must have its basis in the past and be the result of some past event. The recognition of liabilities relies on the identification of the critical event in a continuum of events that triggers the initial recognition of the liability versus other events that affect its measurement. The IASB's approach to financial liabilities focuses on the settlement of a liability being unconditional and unavoidable, which results in a bright-line distinction that has been exploited for structuring hybrid financial instruments such that they meet the definition of equity even if payment of interest and principal is highly probable given certain incentives built into the agreement. As we will show, a less strict definition of 'unavoidable' is applied in other standards that also require constructive obligations to be recognised as a liability.

A contract may entail an obligation for the entity to issue its own equity instruments. According to IAS 32 (para. 11), such contracts qualify as a liability unless the contract can be settled by issuing a fixed number of the entity's shares. According to Bradbury (2003), this approach defines equity more directly than in the $\mathrm{CF}$, which defines it as a residual; recognition of liabilities for the obligation to issue shares is therefore at odds with the existing CF. If equity is the residual, the issuance of equity instruments should not be part of the definition of a liability. More generally, Bradbury (2003) notes that the existing CF is not helpful in dealing with complex hybrid financial instruments. Schmidt (2013) is of the view that a robust principle should be developed for the accounting for such instruments and should be part of the $\mathrm{CF}$, in order to avoid structuring and the need for a range of exceptions at standard level. An example is the exception for the classification of puttable shares. Furthermore, Schmidt (2013) mentions economic compulsion as an example of an aspect for which a principle must be found.

For many companies, material obligations result from lease contracts. As noted by the IASB (2009) and Loftus (2003), such obligations meet all the criteria to be recognised as a liability. However, under IAS 17, only a subset of lease obligations - that is, those arising from finance lease contracts - are recognised as liabilities. The IASB (and FASB) project to develop a new lease standard under which such liabilities are recognised again showed how the IASB has difficulties in reaching well-supported and widely accepted accounting principles based on the concepts in the CF. In the original proposals (IASB 2010a), the IASB concluded that an entity should recognise a liability for all expected future lease payments over the expected lease term, including contingent rentals and payments that only become due when extension options are used. Many respondents commented that recognising liabilities that are avoidable is inconsistent with other standards and that options to extend a lease do not meet the definition of a liability under the $\mathrm{CF}$, because options represent rights and not present obligations. In the revised ED (IASB 2013b), the IASB now proposes to include only the unavoidable payments over the non-cancellable lease term unless the entity has a significant economic incentive to extend the lease. This definition of liability is much closer to the IAS 32 definition, although it does include an aspect of economic compulsion that must be ignored under IAS 32 .

\subsection{Provisions (IAS 37, IFRS 3)}

IAS 37 includes a probable outflow threshold for the recognition of provisions that fall within its scope. The project that was aimed at removing this threshold received negative responses and was put on hold in 2010 (see Section 1 and Rees 2006). However, the recognition threshold does not 
apply to obligations that would normally fall within the scope of IAS 37 when they are acquired as part of a business combination. IFRS 3 requires recognition of contingent liabilities on the balance sheet irrespective of their probability. Furthermore, although the CF gives the same threshold for assets and liabilities, IAS 37 requires a higher level of certainty ('virtually certain') for assets than for liabilities ('probable', defined as more likely than not). In addition to legal obligations, IAS 37 also requires the recognition of liabilities for constructive obligations. According to IAS 37, an established pattern of past practice or published policies can create expectations with the counterparty requiring the recognition of a liability. As a result, the definition of an obligation under IAS 37 can be broader than the definition in IAS 32 in certain aspects (not only contractually or legally unavoidable obligations, but also those arising from past practice or published policies) and more limited in other aspects (only liabilities for which an outflow of economic benefits is probable are recognised).

\subsection{Employee benefits (IAS 19, IFRS 2)}

Neither IAS 19 Employee Benefits nor IFRS 2 Share-based Payment include a probable outflow criterion for the recognition of liabilities for bonuses or cash-settled share-based payments. Although IAS 19 does refer to expected payments, liabilities are recognised when employee services are received, even when the payment is not yet probable (for instance, because it is dependent on a certain share price increase, share price development compared to a group of peer companies, or a specific event such as a succesful IPO). Similar to IAS 37, but contrary to IAS 32, under IAS 19 certain obligations may be recognised for (unvested) employee benefits that are avoidable. Furthermore, contrary to IAS 32, IFRS 2 (para. 41) requires the entity to consider its past practice or stated policy of settling in cash and whether it generally settles in cash even if it is not required to. As a result, an obligation towards the holder of a financial instrument who received this instrument in his or her position as an employee may be classified as a liability, whereas the same instrument is classified as equity when it is held by another party.

\subsection{Deferred and accrued income and costs (IAS 11, IAS 17, IAS 18, IFRIC 13, IAS 20)}

Various IFRSs require accrual or deferral of costs or revenues. For instance, IAS 18 and IFRIC 13 Customer Loyalty Programmes may require deferral of revenues until certain conditions are met such as when significant risks and rewards have transferred (IAS 18.14), when subsequent services have been performed (IAS 18, appendix example 11) or when additional discounted goods or services have been delivered (IFRIC 13). IAS 17 requires accrual or deferral of operating lease income or expenses to allocate total income or expenses evenly over the lease term. This includes lease incentives and, for lessors, the cost of negotiating and arranging an operating lease (IAS 17 paras 33, 50 and 52). According to IAS 11 Construction Contracts (para. 22), contract costs related to a construction contract, including the cost of securing the contract (IAS 11 para. 21), are deferred and spread over the construction period to achieve the recognition of both revenues and costs in accordance with the project's completion stage. Furthermore, IAS 20 Accounting for Government Grants and Disclosure of Government Assistance (para. 12) focuses on the matching principle and states that government grants are recognised in the balance sheet as a reduction of PPE or as deferred income (para. 21) and subsequently released in the income statement over the periods in which the entity recognises as expenses the related costs for which the grants are intended to compensate. These standards focus on the income statement, and the earnings process and may result in assets or liabilities that do not meet the CF definition of an asset or a liability since an inflow or outflow of economic benefits is not expected. 
The obligation to provide goods or services in the future would generally satisfy the definition of a liability. The recognition and measurement of such liabilities in current IFRSs is however primarily focused on the earnings process instead of on the definition of an asset or a liability. According to Samuelson (1993), with reference to the FASB's CF, the liability to provide goods or services should reflect the probable future outflow of economic benefits (sacrifices) that are required to fulfil the obligation. Depending on the probability of a refund of an advance payment and whether the seller has an opportunity cost of foregone revenues (when the sale prevents him or her from selling to others), the liability may be significantly lower than the deferred revenues recognised or may not even exist. The IASB's focus on the earnings process may result in different accounting for the same obligation, depending on whether the obligation arose from an earnings process or otherwise. This is illustrated by the following example:

Retailer R is running a temporary offer by which a customer who buys a bottle of shampoo receives a voucher that entitles the customer to a $50 \%$ discount on a bottle of conditioner which can be used the week after. In week 1, R sells 100,000 bottles of shampoo, and estimates that half of the customers will use the voucher to buy conditioner in week 2 . R will still make a profit on sales at a $50 \%$ discount.

As part of a marketing campaign, in week 1, retailer $\mathrm{S}$ has distributed 100,000 vouchers to households in its area. The vouchers entitle a customer to a $50 \%$ discount on a bottle of conditioner in week 2 . S estimates that half of the recipients of vouchers will use them. S will still make a profit on sales at a $50 \%$ discount.

At the end of week 1, both retailers $\mathrm{R}$ and $\mathrm{S}$ expect to be obliged to sell 50,000 bottles of conditioner at a $50 \%$ discount in week 2 and make a profit on those sales. Based on IFRIC 13, an interpretation of IAS 18 , R must recognise a liability for its obligation to deliver bottles of conditioner in the future at a discount. Since S's obligation does not arise from a sales transaction, $\mathrm{S}$ does not recognise a liability because the future sales to customers with vouchers does not result in an outflow of economic benefits. Although the economic positions of R and $\mathrm{S}$ at the end of week 1 are exactly the same, the accounting for the obligation is different, depending on whether it arose from a sales process or otherwise. According to Samuelson (1993), this is due to the fact that, in certain standards, the focus is on the earnings process at the expense of appropriate application of the definitions of asset and liability. The ongoing discussions about rate-regulated activities have a similar background, with proponents of a focus on earnings/matching disagreeing with proponents of a strict application of the definitions of assets and liabilities.

Also in relation to assets, Samuelson (1996) notes that the current definitions mix the concept of stocks (assets) with flows and allow for deferral of costs based on the expectation that they will be recovered by future economic benefits. He is of the view that the primary focus in the definition of an asset should be on the (property) right of the entity, and that all deferred costs that are not rights of the entity should be eliminated from the balance sheet. His view is shared by Chambers (1996) who states that (p. 121) 'assets, once considered by accountants to be exchangeable goods and rights, came to be described as unamortized costs, which are not real world phenomena' and (p. 128) "no-one drives to work in a "probable future benefit".

\subsection{Deferred tax assets and liabilities (IAS 12)}

According to IAS 12 Income Taxes, deferred tax liabilities are recognised for all taxable temporary differences, except when certain specific exceptions apply. However, deferred tax assets are only recognised when future taxable profits are probable. The current standard thus only applies the probability threshold from the CF to assets and not to liabilities, whereas the orginal standard 
IAS 12 Accounting for Taxes on Income issued in 1979 required that both deferred tax assets and deferred tax liabilities were only recognised if these would reverse in the projected future. Also UK GAAP in the past required under the partial approach that both deferred tax assets and deferred tax liabilities were subject to a probability threshold (see Gordon and Joos 2004). Furthermore, the various exceptions in the standard, such as the initial recognition exception, indicate that the purpose of deferred taxes is primarily to match the income tax effect in the income statement to the profit before tax as determined under IFRS rather than to recognise assets and liabilities that meet the definition of the CF. The comprehensive interperiod income tax allocation model behind IAS 12 has been subject to debate and analysis by various academics; see, for instance, Chambers (1968), Barton (1970) and Buckley (1972) prior to the issuance of the orginal IAS 12 and the CF, and therafter Guenther and Sansing (2000) and Laux (2013). In the light of the definitions of an asset and a liability, it is interesting to see that many analyses and discussions continue to focus on the question whether it would be appropriate to apply a matching principle to income taxes. Those in favour of the recognition of deferred income taxes consider income tax as an expense which should be matched with the related profits, whereas others view income tax as a distribution similar to dividends for which a matching concept is inappropriate. This angle in the discussion suggests that accounting for deferred tax is indeed driven by a matching principle rather than by pure application of the definitions of asset and liability. Furthermore, Guenther and Sansing (2000) argue that differences between tax and book depreciation result in temporary differences but are not associated with future tax cash flows. According to Loftus (2003), deferred tax liabilities do not meet the definition of a liability in the CF, because the entity has no present obligation to the tax authorities, and - instead - are deferred debits and credits. According to Chambers (1968), interperiod income tax allocation, which underlies the current model used in IAS 12, can therefore only be justified based on prudence.

Others have tried to shed light on this matter by investigating the value relevance of deferred tax assets and liabilities. Some find evidence that deferred taxes are relevant (e.g. Ayers 1998, Amir and Sougiannis 1999), but others find some contrary evidence (e.g. Amir et al. 1997, Chludek 2011). The research of Laux (2013) provides some explanation for the mixed results. He concludes that the value relevance depends on whether deferred tax is predictive of future tax cash flows. He distinguishes between transactions that are accounted for in the financial statements at a later date than they appear in the tax return (TAX-first) and those that are recognised in the financial statements first and appear in the tax return at a later date (GAAP-first). Laux concludes that only deferred taxes resulting from GAAP-first events are predictive of future tax cash flows. If so, only GAAP-first deferred taxes meet the definition of an asset or a liability (given that they are expected to result in a future tax cash flow), whereas TAX-first deferred taxes are deferred debits or credits used for achieving a match between accounting income before tax and the income tax expense.

Two main observations arise from the research into the accounting for deferred taxes. First, the accounting model for deferred taxes which underlies IAS 12 contains elements of conservatism. Second, the model results in (deferred) tax liabilities that do not result in de facto tax cash outflows and thus do not meet the CF's criterion of an expected future outflow of economic benefits.

One might argue that deferred tax assets and liabilities represent the fact that future tax payments will be lower or higher than the expected tax payment based on accounting profit and statutory tax rates. However, this in itself does not justify the recognition of an asset or a liability. Deferred tax assets are, for instance, not recognised either when (other) options in tax law are applied that result in an expected future effective tax rate below the statutory tax rate or when an entity is, for tax purposes, located in a country in which lower taxes are paid than elsewhere. On a very similar topic - regulatory assets and liabilities - the IASB and IFRIC have used a stricter application of the definitions of asset and liability. ${ }^{7}$ It has been concluded that the right to 
charge higher tariffs in the future or the obligation to charge lower tariffs in the future are not assets and liabilities as defined in the CF (unless it results in the obligation to deliver goods or services at a loss, resulting in an actual outflow of benefits which would qualify as a liability). Furthermore, the many exceptions in the standard, like the initial recognition exception for assets or liabilities acquired outside a business combination and for goodwill, indicate that this rationale does not drive deferred tax accounting. The justification for deferred taxes is the matching of income and (tax) expenses.

\subsection{Evaluation of the application of the current CF definitions}

Our analysis shows that, at standard level, the IASB has not consistently applied the definitions and recognition criteria from the CF. Specifically, the probability thresholds in the asset and liability definitions and recognition criteria have regularly not been applied when developing accounting standards. Many standards require assets or liabilities to be recognised even if an inflow or outflow of economic benefits is not probable, such as financial instruments under IAS 32/39 and employee-related obligations under IAS 19 and IFRS 2. Furthermore, certain assets and liabilities are treated differently depending on how they arise and are, for instance, recognised under IFRS 3 when they arise from a business combination, whereas they are not recognised when developed by the business. Which standard applies to an item can make a significant difference to whether or not the item is recognised as an asset or a liability. Whether an obligation falls within the scope of IASs 32, 37 or 19 can, for instance, make a substantial difference. The IASB's view on accounting for (operating) leases varies from not recognising assets and liabilities (IAS 17), to recognising assets and liabilities based on all expected payments under the existing contracts including extensions (first lease ED of 2010), to recognising assets and liabilities for the unavoidable lease payments (second lease ED of 2013). This range of views indicates that the definitions and recognition criteria for assets and liabilities under the existing CF did not determine the standard setting. It suggests that the CF concepts might not be sound.

Furthermore, although explicitly forbidden in the CF, current IFRS nevertheless allows certain items to be recognised on the balance sheet based on a matching principle. Examples are deferred government grants under IAS 20 and deferred costs under IAS 11. Also, the recognition of deferred taxes and acquired goodwill seem to be driven by the desire to match income and expenses and/or to defer costs, whereas it is questionable whether they (always) meet the CF's definitions of asset and liability. Finally, prudence is present in various accounting standards, although the $1989 \mathrm{CF}$ warned against its effect on neutrality and the concept has been removed from the qualitative characteristics in the $2010 \mathrm{CF}$. However, accounting standards such as IAS 12 (deferred tax assets versus deferred tax liabilities) and IAS 37 (contingent assets versus contingent liabilities) contain a higher recognition threshold for assets than for liabilities.

The inconsistencies between these standards and between standards and the CF may be the result of new thinking that developed over time and that should now be reflected in the DP. We therefore assessed whether early standard setting showed evidence of inclusion of the probability thresholds in recognition criteria (in line with the CF of 1989), whereas newly emerged thinking about recognition drove standard setting more recently. The latest version of IAS 12 was issued in 1996 and did include a probability-based recognition threshold for deferred income tax assets but not for liabilities. IAS 37 was issued in 1998 and includes a probability threshold for the recognition of non-financial liabilities whereas IAS 39 of 1999 does not include such a threshold for financial assets and liabilities. This shows that, relatively soon after the CF was issued (within 10 years), the IASC applied the probability threshold in one standard and ignored it in another and even allowed inconsistency within one standard (IAS 12). 
In the years thereafter, the IASB issued standards that do not have a probability-based recognition threshold, such as IFRS 2 in 2004 and IFRS 3 in 2010 but also published a Staff Paper in 2010 stating that it intended to maintain a probability assessment for non-financial liabilities and issued IFRS 15 in 2014 which does include probability thresholds in relation to collectability and (variable) consideration. Altogether, these standard-setting activities do not show a clear change in thinking over time about whether a probability-based recognition threshold should generally apply for the recognition of assets and liabilities but rather show inconsistency with the CF in the thinking about this matter that already existed in 1996 (only seven years after the release of the CF) and continued until 2014 (after the DP had been issued).

In order to understand the reasons that the IASB may have had to deviate from this aspect of the existing CF when developing the above-mentioned standards, we have also analysed arguments used in the Bases for Conclusions (BCs) accompanying these standards. IAS 12 did not include a BC and therefore no insight is obtained into the IASB's thinking that resulted in deviating from the CF's probability threshold with regard to the recognition of deferred tax liabilities. IAS 37 also did not include a $\mathrm{BC}$ either but did comply with the $\mathrm{CF}$ in relation to the probability thresholds for recognition of liabilities (for contingent assets it actually requires a higher threshold than probable). The BCs to IAS 39 and IFRS 2 do not provide insight into the Board's considerations to reflect probability of future cash flows in the measurement of financial assets and liabilities and share-based payment liabilities instead of including probability in the recognition criteria as the $\mathrm{CF}$ indicates. The $\mathrm{BC}$ to IFRS 3 is more specific about the IASB's consideration not to include probability requirements for the recognition of assets and liabilities acquired in a business combination. According to IFRS 3 (BC130) 'the IASB decided that inclusion of the probability criterion in the revised IFRS 3 is unnecessary because an unconditional right or obligation will always satisfy the criterion'. In relation to contingent consideration, according to IFRS 3 (BC346) 'failure to recognise that obligation or right at the acquisition date would not faithfully represent the economic consideration exchanged at that date'. In BC130 the IASB seems to ignore the fact that the CF does include a probability threshold and suggests that it is an unnecessary requirement since an unconditional right or obligation always meets the (probability) requirements. As discussed in this paper, this is not necessarily true. In BC346, the IASB defends its deviation from the CF with a reference to faithful representation. In the 2010 Staff Paper about Liabilities (IASB 2010b), the IASB states that, in order to provide useful and relevant information, entities should recognise all of their liabilities (not only those for which an outflow of economic benefits is probable) and that proposed changes should be seen in the context of the IASB's intention to change the CF. However, in relation to revenue recognition (IFRS 15), the IASB did include probability-based thresholds and supported this decision with reference to relevance for the users of the financial statements and furthermore stated that 'specifying a level of confidence would provide clarity and thus ensure more consistent application of the requirements' (IFRS 15 BC209). Faithful representation, usefulness and relevance have thus been brought forward as arguments for not including a probability threshold in some standards whereas relevance, clarity and consistency have been brought forward as arguments to include a probability threshold in another standard.

\section{The DP and its potential impact on assets and liabilities in future standard setting}

\subsection{Proposed changes to the definitions and recognition criteria for assets and liabilities}

In the feedback statement on its 2011 Agenda Consultation, the IASB (2012) reports that most respondents thought that it should give priority to developing a sound CF. Specifically in relation to the definitions of asset and liability, the feedback statement (p. 22) states that: 
Many respondents think that clarifying the definition of assets and liabilities is a prerequisite for resolving a number of issues. A clear definition of assets would be the starting point for a project on intangibles. Respondents say that such a project would provide insight into developing guidance on rate-regulated industries and extractive activities.

The IASB responded that (p. 22) 'the recent standards level work in the Leases, Emission Trading Schemes, Rate-Regulated Activities and Non financial Liabilities projects has highlighted that those definitions did not provide the IASB with clear enough guidance to solve some difficult issues'.

The objective of the revised definitions and recognition criteria in the DP is thus to provide clearer guidance to the IASB for developing standards on the recognition of specific assets or liabilities, such as non-financial liabilities and those resulting from leases and rate-regulated activities. In this section, we analyse the extent to which the revised definitions and recognition principles have the potential to achieve this objective.

After completing the sections on the objective of general purpose financial reporting and qualitative characteristics in 2010, the DP of 2013 discusses other aspects of the new CF, including proposed new definitions and recognition criteria for assets and liabilities. The IASB suggests removing the probability thresholds from the definitions and the recognition criteria. In the DP, assets and liabilities are defined as follows (para. 2.11):

- an asset is a present economic resource controlled by the entity as a result of past events.

- a liability is a present obligation of the entity to transfer an economic resource as a result of past events.

According to Booth (2003), the old definition of an asset was not fully clear about whether the asset is the right to future benefits or the benefits as such. This has been clarified by the IASB in the DP and is reflected in the amended definition. According to the DP (para. 2.10), 'an asset is a resource (rather than the inflow of economic benefits that the resource may generate)'. Similarly (DP para. 2.10), 'a liability is an obligation (rather than the outflow of economic benefits that the obligation may generate)'. The revised definition also addresses some of the criticism by Samuelson (1996) by removing the reference to future economic benefits from the definition of an asset and focusing instead on the control of a resource. The DP proposes to deal with economic benefits and uncertainty as part of measurement.

The DP not only proposes removing outcome uncertainty, it also does not consider existence uncertainty in the definition of an asset or a liability. As indicated by the IASB as part of the liabilities project, existence uncertainty may be relevant in relation to lawsuits when an entity should assess whether it has an obligation that should be provided for, but according to the DP, existence uncertainty is rarely an issue and is therefore not considered further. The IASB furthermore proposes (DP paras 4.24-4.26) that all assets and liabilities should be recognised except when either recognition would not result in relevant information or because no measure would result in a faithful representation of the asset or liability or changes. No indicators are provided for the faithful representation aspect, but various indicators are given for relevance (e.g. extremely wide range of possible outcomes, measuring requires unusually or exceptionally subjective allocations of cash flows) and these may really be indicators for faithful representation.

According to the DP (para. 9.19), many objected to the removal of prudence from the CF because they are of the view that this could result in the recognition of assets and gains whose existence is uncertain and the non-recognition of some possible liabilities and possible losses. However, the IASB suggested that the idea that a preparer should exercise caution when making estimates and judgements under conditions of uncertainty is sufficiently reflected in many of the decisions that the IASB makes when setting standards (DP para. 9.20) and refers 
to Section 2 of the DP for its proposed future approach on dealing with uncertainty. However, Section 2 of the DP is clear that the IASB proposes to fully remove the reference to probability from the definitions in the $\mathrm{CF}$ and does not elaborate in more detail on this.

\subsection{Analysis of the impact of the proposed changes}

We now analyse the extent to which the proposed changes to the definitions of asset and liability as well as the proposed recognition criteria provide a new conceptual basis for the development of consistent standards and eliminate the inconsistencies in current accounting standards. Even though the IASB indicates (DP para. 1.22) that the new CF will not be followed by an immediate revision of all accounting standards that are inconsistent with it and the IASB may even allow itself to deviate from the CF in the future (DP, para. 1.32), the new CF should presumably be generally applied as a basis for new standards and revisions, thereby gradually aligning the standards to the new CF. The IASB has not yet presented a final proposal for the approach to conditional obligations that depend on the entity's future actions and how constructive obligations should or should not be considered in this regard. This aspect is therefore not included in our analysis.

In a Staff Paper, the IASB (2014a, p. 6) states that: 'its aim in revising the definitions of an asset and of a liability and the recognition criteria was to provide more clarity, not to broaden or narrow the range of recognised assets and recognised liabilities'. This indicates that the IASB expects that the newly developed definitions and concepts of the DP will support the choices that had been made in developing IFRSs in prior years. Table 1 therefore summarises the results of our analysis of various potential assets and liabilities concerning whether or not they meet the current CF definition of an asset or a liability, whether they are recognised under current IFRSs, whether they meet the definition of asset or liability proposed in the DP and whether, based on considerations of relevance or faithful representation, the DP would support the continued non-recognition of assets or liabilities that do meet the DP's proposed definitions.

The analysis presented in Table 1 provides a number of insights. First, in those instances where assets or liabilities are recognised under existing IFRSs although not meeting the definitions or recognition criteria in the existing CF because an inflow or outflow of economic benefits is not probable, the inconsistency between IFRSs and the CF will be resolved if the proposals from the DP are implemented in the new CF. This applies to derivatives that are recognised under IAS 39, contingent consideration that is recognised based on IFRS 3 (liabilities) or IFRS 10 (assets), various assets and liabilities recognised based on a purchase price allocation in accordance with IFRS 3, employee benefit liabilities under IAS 19 and IFRS 2, and deferred tax liabilities under IAS 12. These items are currently recognised even if an inflow or outflow of economic benefits is not probable, but this would be resolved by implementing the DP proposals in a new CF that removes this threshold. Furthermore, the DP would support the IASB's initial proposals as part of the Liabilities project to remove the probability threshold for the recognition of provisions and may give the IASB a basis to re-open the discussions on this topic. It would also allow for the maintainance of the current model based on the argument of low probability. Furthermore, the DP supports the most recent proposals for the revision of lease accounting.

Table 1 also shows that the removal of the requirement for probable future inflows or outflows of economic benefits could require recognition of various assets and liabilities that are not recognised under current IFRSs. This includes provisions as well as various internally developed intangible assets, variable consideration on the sale of goods or services, royalties and deferred tax assets. However, the guidance in relation to recognition laid out in Section 4 in the DP, would provide the IASB and other stakeholders with arguments to continue not recognising these assets and liabilities, depending on how broadly the arguments were applied in practice. The DP, for instance, refers to low probability, an extremely wide range of possible outcomes, 
Table 1. Analysis of the impact the new definitions and recognition criteria on the recognition of assets and liabilities under IFRS.

\begin{tabular}{|c|c|c|c|c|}
\hline Item & $\begin{array}{l}\text { Meets } \\
\text { definition } \\
\text { current CF }\end{array}$ & $\begin{array}{l}\text { Recognised } \\
\text { today }\end{array}$ & $\begin{array}{l}\text { Meets } \\
\text { definition } \\
\text { DP }\end{array}$ & $\begin{array}{l}\text { Possible arguments to continue } \\
\text { not recognising based on } \\
\text { relevance and faithful } \\
\text { representation }\end{array}$ \\
\hline \multicolumn{5}{|l|}{ Tangible fixed assets } \\
\hline $\begin{array}{l}\text { PP\&E under IAS 16, IAS } \\
40\end{array}$ & Yes & Yes & Yes & N/A \\
\hline $\begin{array}{l}\text { Finance leases under IAS } \\
17\end{array}$ & Yes & Yes & Yes & N/A \\
\hline $\begin{array}{l}\text { Operating leases under } \\
\text { IAS } 17\end{array}$ & Yes & $\mathrm{No}^{\mathrm{a}}$ & Yes & $\mathrm{N} / \mathrm{A}^{\mathrm{a}}$ \\
\hline \multicolumn{5}{|l|}{ Intangible assets } \\
\hline Acquired goodwill & Yes?? ${ }^{\mathrm{b}}$ & Yes & Yes?? ${ }^{\mathrm{b}}$ & N/A \\
\hline $\begin{array}{l}\text { Acquired other (directly } \\
\text { or via business } \\
\text { combination) }\end{array}$ & Yes & Yes & Yes & N/A \\
\hline $\begin{array}{l}\text { Internally generated } \\
\text { goodwill }\end{array}$ & Yes?? $^{\mathrm{b}}$ & No & Yes?? $^{\mathrm{b}}$ & $\begin{array}{l}\text { Not necessary to meet the } \\
\text { objective of financial } \\
\text { reporting } \\
\text { No identifiable resource } \\
\text { Measurement highly subjective }\end{array}$ \\
\hline $\begin{array}{l}\text { Development costs - } \\
\text { benefits not expected }\end{array}$ & No & No & Yes & Low probability \\
\hline $\begin{array}{l}\text { Development costs - } \\
\text { benefits expected }\end{array}$ & Yes & Yes & Yes & N/A \\
\hline $\begin{array}{l}\text { Internally generated, } \\
\text { excluding } \\
\text { development }\end{array}$ & Yes & No & Yes & $\begin{array}{l}\text { Not necessary to meet the } \\
\text { objective of financial } \\
\text { reporting } \\
\text { Measurement highly subjective } \\
\text { Low probability }\end{array}$ \\
\hline \multicolumn{5}{|l|}{ Financial assets } \\
\hline $\begin{array}{l}\text { Regular, collectable, } \\
\text { receivables }\end{array}$ & Yes & Yes & Yes & N/A \\
\hline $\begin{array}{l}\text { Derivatives - benefits } \\
\text { expected }\end{array}$ & Yes & Yes & Yes & N/A \\
\hline $\begin{array}{l}\text { Derivatives - benefits } \\
\text { not expected }\end{array}$ & No & Yes & Yes & N/A \\
\hline $\begin{array}{l}\text { Contingent consideration } \\
\text { IFRS } 10 \text { - benefits } \\
\text { expected }\end{array}$ & Yes & Yes & Yes & N/A \\
\hline $\begin{array}{l}\text { Contingent consideration } \\
\text { IFRS } 10-\text { benefits not } \\
\text { expected }\end{array}$ & No & Yes & Yes & N/A \\
\hline $\begin{array}{l}\text { Variable consideration } \\
\text { IAS } 18 \text { - benefits } \\
\text { probable }\end{array}$ & Yes & $\mathrm{No}^{\mathrm{c}}$ & Yes & $\begin{array}{l}\text { Wide range of possible } \\
\text { outcomes and difficult to } \\
\text { estimate }\end{array}$ \\
\hline $\begin{array}{l}\text { Variable consideration } \\
\text { IAS } 18 \text { - benefits not } \\
\text { expected }\end{array}$ & No & No & Yes & Low probability \\
\hline Inventories & Yes & Yes & Yes & N/A \\
\hline
\end{tabular}


Table 1. Continued.

\begin{tabular}{|c|c|c|c|c|}
\hline Item & $\begin{array}{l}\text { Meets } \\
\text { definition } \\
\text { current CF }\end{array}$ & $\begin{array}{l}\text { Recognised } \\
\text { today }\end{array}$ & $\begin{array}{l}\text { Meets } \\
\text { definition } \\
\text { DP }\end{array}$ & $\begin{array}{l}\text { Possible arguments to continue } \\
\text { not recognising based on } \\
\text { relevance and faithful } \\
\text { representation }\end{array}$ \\
\hline \multicolumn{5}{|l|}{ Financial liabilities } \\
\hline $\begin{array}{l}\text { Regular liabilities } \\
\text { (including finance } \\
\text { leases) }\end{array}$ & Yes & Yes & Yes & N/A \\
\hline Operating lease liabilities & Yes & $\mathrm{No}^{\mathrm{a}}$ & Yes & $\mathrm{N} / \mathrm{A}^{\mathrm{a}}$ \\
\hline $\begin{array}{l}\text { Derivatives - outflow } \\
\text { expected }\end{array}$ & Yes & Yes & Yes & N/A \\
\hline $\begin{array}{l}\text { Derivatives - outflow } \\
\text { not expected }\end{array}$ & No & Yes & Yes & N/A \\
\hline $\begin{array}{l}\text { Contingent consideration } \\
\text { IFRS } 3 \text { - outflow } \\
\text { probable }\end{array}$ & Yes & Yes & Yes & N/A \\
\hline $\begin{array}{l}\text { Contingent consideration } \\
\text { IFRS } 3 \text { - outflow not } \\
\text { probable }\end{array}$ & No & Yes & Yes & N/A \\
\hline \multicolumn{5}{|l|}{ Provisions } \\
\hline $\begin{array}{l}\text { Obligation - outflow } \\
\text { expected }\end{array}$ & Yes & Yes & Yes & N/A \\
\hline $\begin{array}{l}\text { Obligation - outflow not } \\
\text { expected IAS } 37\end{array}$ & No & $\mathrm{No}^{\mathrm{d}}$ & Yes & Low probability \\
\hline $\begin{array}{l}\text { Obligation - outflow not } \\
\text { expected IFRS } 3\end{array}$ & No & Yes & Yes & N/A \\
\hline \multicolumn{5}{|c|}{ Employee benefits (IAS 19, IFRS 2) } \\
\hline $\begin{array}{l}\text { Regular salaries, } \\
\text { pensions, bonuses and } \\
\text { similar benefits }\end{array}$ & Yes & Yes & Yes & N/A \\
\hline $\begin{array}{l}\text { Cash settled share-based } \\
\text { payment - outflow } \\
\text { expected }\end{array}$ & Yes & Yes & Yes & N/A \\
\hline $\begin{array}{l}\text { Cash settled share-based } \\
\text { payment - outflow not } \\
\text { expected }\end{array}$ & No & Yes & Yes & N/A \\
\hline $\begin{array}{l}\text { Bonus payable upon } \\
\text { future event - outflow } \\
\text { expected }\end{array}$ & Yes & Yes & Yes & N/A \\
\hline $\begin{array}{l}\text { Bonus payable upon } \\
\text { future event }- \text { outflow } \\
\text { not expected }\end{array}$ & No & Yes & Yes & N/A \\
\hline \multicolumn{5}{|l|}{ Deferred costs or income } \\
\hline $\begin{array}{l}\text { Deferred revenues - cost } \\
\text { of future delivery } \\
\text { higher than proceeds }\end{array}$ & Yes & Yes & Yes & N/A \\
\hline $\begin{array}{l}\text { Deferred revenues - cost } \\
\text { of future delivery } \\
\text { lower than proceeds }\end{array}$ & No & Yes & No & N/A \\
\hline $\begin{array}{l}\text { Deferred costs of } \\
\text { securing construction } \\
\text { contract IAS } 11\end{array}$ & No & Yes & No & N/A \\
\hline
\end{tabular}


Table 1. Continued.

\begin{tabular}{|c|c|c|c|c|}
\hline Item & $\begin{array}{c}\text { Meets } \\
\text { definition } \\
\text { current CF }\end{array}$ & $\begin{array}{l}\text { Recognised } \\
\text { today }\end{array}$ & $\begin{array}{l}\text { Meets } \\
\text { definition } \\
\text { DP }\end{array}$ & $\begin{array}{l}\text { Possible arguments to continue } \\
\text { not recognising based on } \\
\text { relevance and faithful } \\
\text { representation }\end{array}$ \\
\hline $\begin{array}{l}\text { Deferred government } \\
\text { grants }\end{array}$ & No & Yes & No & N/A \\
\hline \multicolumn{5}{|c|}{ Deferred tax assets and liabilities (IAS 12) } \\
\hline $\begin{array}{l}\text { Deferred tax assets carry } \\
\text { forward losses - } \\
\text { benefits expected }\end{array}$ & Yes & Yes & Yes & N/A \\
\hline $\begin{array}{l}\text { Other deferred tax assets } \\
- \text { benefits expected }\end{array}$ & Yes?? & Yes & Yes?? & $\mathrm{N} / \mathrm{A}$ \\
\hline $\begin{array}{l}\text { Deferred tax assets - } \\
\quad \text { benefits not expected }\end{array}$ & No & No & Yes?? & Low probability \\
\hline $\begin{array}{l}\text { Deferred tax liabilities - } \\
\text { outflow expected }\end{array}$ & Yes?? & Yes & Yes?? & N/A \\
\hline $\begin{array}{c}\text { Deferred tax liabilities - } \\
\text { outflow not expected }\end{array}$ & No & Yes & Yes?? & N/A \\
\hline
\end{tabular}

Notes: This table summarises the results from our analysis of various potential assets and liabilities concerning whether they meet the current CF definition of an asset or liability, whether they are recognised under current IFRSs, whether they meet the definition of an asset or liability as proposed in the DP and whether, based on considerations of relevance or faithful representation, the IASB could justify continuing to not recognise assets or liabilities that do meet the proposed definition of an asset or liability in the DP.

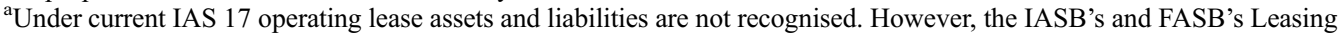
project and ED propose recognition.

${ }^{b}$ According to the IASB, (parts of) goodwill meets the definition of an asset. However, some academic literature concludes that goodwill does not meet the definition of an asset (e.g. see Booth 2003).

${ }^{c}$ Although, according to IAS 18 , revenue is recognised when the inflow of economic benefits is probable, the other criteria such as transfer of significant risks and rewards and reliable measurement generally put a high hurdle on the recognition of variable consideration. Also, in the development of a new revenue recognition standard, the IASB decided to include a high threshold to recognising variable consideration (not if it concerns sales- or usage-based royalties and otherwise only if it is highly probable that the amount of revenue will not be reversed in the future).

${ }^{\mathrm{d}}$ It is noted that in its project on liabilities, the IASB proposed to remove the probability threshold for provisions, but put the project on hold owing to a lack of support for this proposal.

eAccording to the IASB, deferred tax assets and liabilities meet the definition of assets and liabilities. However, some academics conclude that, at best, only a subset of deferred taxes meets the definition (for instance, see Loftus 2003 and Laux 2013).

unusually difficult or exceptionally subjective allocations of cash flows, and (absence of) necessity of recognition to meet the objectives of financial reporting. When these aspects are described at a conceptual level in the future $\mathrm{CF}$, in the bargaining process that is inherent to developing accounting standards (e.g. see Peasnell 1982, Gerboth 1987, Zeff 2002), each stakeholder will be able to find at least some arguments for recognising or not recognising assets or liabilities. This process is similar to that described by Watts and Zimmerman (1979) whereby each stakeholder will find an accounting theory supporting his or her views. Watts and Zimmerman (1979) are of the view that, as a result of the political process, rationales will differ across accounting standards. It also provides room for justification of individual standard-setting decisions using bits and pieces from an incoherent $\mathrm{CF}-$ as described by Newberry (2003). The IASB discusses comparability as an enhancing qualitative characteristic in the $\mathrm{CF}$, but does not identify consistency between IFRSs as an objective, qualitative characteristic or requirement, and thus leaves room for decision-making about relevance and faithful representation on a standard-by-standard basis.

Second, it is not clear from the DP whether the newly proposed definitions would bring an end to cost and income deferrals. As discussed in the previous section, current IFRSs require recognition of items on the balance sheet that have the nature of deferral of cost or income (goodwill, certain 
deferred revenues) or matching items (certain deferred tax liabilities) rather than meeting the definitions of asset or liability. As indicated in Table 1, the proposed new definitions do not provide a clear solution to this. An asset is now defined as a present economic resource controlled by the entity, and a liability as a present obligation to transfer an economic resource. The discussion and academic literature summarised in the previous section in relation to items such as goodwill, deferred tax and deferred income are still valid based on the new definitions. However, the DP's discussion of goodwill and deferred tax suggests that the IASB believes that goodwill and deferred tax are assets and liabilities according to the definitions of the DP and that it does not expect significant changes in relation to these items. Also, the development of IFRS 15 that took place in parallel to developing the DP does not indicate a fundamental change from the current approach to revenue recognition, focusing as it does on the completion of a revenue process instead of on assets and liabilities.

\subsection{Reflection of latest thinking or a reverse-engineered CF?}

Our analysis shows that the recognition of various assets and liabilities based on existing standards that are in conflict with the current CF will generally be in accordance with the proposals included in the DP. A cynical view of the IASB's efforts to develop a new CF might lead to the conclusion that it is solely a political step aimed at gaining credibility and legitimacy, creating the appearance of coherence and legitimising existing practice (as described by Peasnell 1982, Hines 1989, 1991, Walker 2003, O’Brien 2009). As noted earlier, a different view is however presented by McGregor and Street (2007). They state that, when thinking has changed, it may not be right to base new standards on old thinking, and that waiting or redevelopment of the CF before a new standard is issued may negatively affect accounting standards' timeliness.

If thinking about concepts has changed over time and this is reflected in a new $\mathrm{CF}$, we would expect conclusions about the recognition of assets or liabilities also to change, especially in areas where standards were developed many years ago. The DP however is likely to support the existing thresholds for asset recognition that are included in various existing standards (IASs 16, 37, 38 and IFRS 15) based on one of the indicators that recognition might not result in relevant information (DP para. 4.26) whereas it now also supports those standards that do not include such a threshold. Furthermore, according to respondents to the IASB's Agenda Consultation and the IASB's response (IASB 2012), the new CF should provide clear guidance for developing standards on, for instance, leases, rate-regulated activities and intangibles. Our analysis shows that the current proposals add little clarity and little new insight into the appropriate accounting in these areas. All problems raised and inconsistencies identified in relation to acquired goodwill and a range of internally generated intangible assets, as summarised in this paper, are equally relevant under the DP as they are under the current $\mathrm{CF}$. The answer to the question whether future tariff increases or decreases under rate regulation are assets and liabilities, and the same question in relation to future higher or lower tax payments under tax regulation (i.e. deferred taxes) become no clearer based on the definitions and recognition criteria in the DP. The proposals in the DP shed no new light on the conclusions already reached in the leasing project and resulting ED. This leads us to conclude that the IASB has not yet met the stated objective of developing a robust and consistent basis for future standard setting and providing clearer guidance to solve issues in areas such as leases, rate-regulated activities and nonfinancial liabilities. This brings us to another point arising from the DP.

\subsection{The CF as a robust basis for preparers to make judgements in developing and applying accounting policies?}

The primary purpose of the new CF is to be the basis for the IASB's standard setting (DP para. 1.26). However, when no specific IFRS exists for a transaction or item, IAS 8 (para. 11) requires 
an entity to apply the definitions, recognition criteria and measurement concepts from the CF for developing and applying an accounting policy for this transaction or item. If the DP's ideas were to be reflected in the new $\mathrm{CF}$, this would require an assessment by the entity about whether recognition of an asset or a liability would result in relevant information and whether it could be measured at a basis that would result in a faithful representation of the asset or liability. The approach taken in the DP however facilitates using a CF in the way that Newberry (2003) describes, providing room for justification of individual decisions using bits and pieces from the $\mathrm{CF}$, instead of serving as a a solid technical basis resulting in consistent decision making about accounting policies. Thus, the DP's proposals would not only give more flexibility to the IASB in reaching conclusions about recognising assets or liabilities, it would also give it to entities in cases when no specific standard applies. This will reduce consistency between entities in their accounting for those transactions and items, because it will depend on management's assessment of the aspects of relevance and faithful representation.

Given the subjective nature and potential entity-specific incentives that affect management's judgement, it might be more appropriate to leave this assessment entirely to the IASB as part of its standard setting process. However, this would require that entities would no longer need to apply these concepts from the CF in developing their own accounting policies. This could be achieved by including separate sections in the CF with principles and criteria for the IASB to apply when developing standards, and separate (less subjective) criteria that entities should apply in the absence of specific standards. An alternative would be that the IASB ensures that all possible items and transactions are dealt with in individual standards.

At first glance, this may not look like an attractive direction under principles-based accounting, and such an approach may develop into rules-based accounting, whereby for each transaction or item there is a need for guidance in a separate standard. However, in our view, this is not necessarily the case. The concepts of the CF can be translated into a separate standard that contains principles for the recognition and measurement of assets and a standard that contains principles for the recognition and measurement of liabilities that apply in all cases when no other standard applies. Such a standard would be the 'catch-all-the-rest' standard that can only be applied when a transaction or item does not fall into any of the other standards and none of the other standards can be applied by analogy and thus basically take over the role that the existing CF would have in such cases. Such a standard could well be principles based.

To illustrate how such a model would work, let us take liabilities as an example. The IASB has developed and may revise standards on specific liabilities relating to employee benefits (IAS 19), share-based payments (IFRS 2), income tax (IAS 12) and financial instruments (IAS 39 or IFRS 9). The scope paragraphs of those standards define to which liabilities these standards specifically apply. If an entity needs to account for an item that is excluded from scope of all these standards but does meet the definition of a liability, based on IAS 8.11 management would consider the definitions and recognition criteria from the $\mathrm{CF}$ and apply its judgment in relation to the indicators for relevance and faithful representation as included in the new CF. Such a situation could be avoided by developing a standard for 'Other liabilities' that applies to all items that meet the definition of a liability of the new CF, but is not in scope of any of the other specific standards. This could also include more specific guidance on probability and measurement uncertainty (wide range of possible outcomes). Development of such standards for assets and liabilities would avoid the need for preparers to apply the new CF and make their own assessment of how to interpret and apply the indicators. The indicators would only be applied by the IASB in their standard setting activities, whereas preparers would apply the more specific principles for asset or liability recognition. 


\section{Conclusions and recommendations}

We investigated the definitions and recognition criteria for assets and liabilities in the CF and DP, and analysed their impact on IFRS requirements for the recognition of assets and liabilities. We explored how the IASB has applied the definitions and recognition criteria in the existing CF, and whether the new definitions, recognition criteria and related explanations in the DP would provide a robust basis for the development of consistent and coherent accounting standards. For this purpose, we chose to focus on assets and liabilities, because they are the crucial basis for the current balance sheet focused accounting model.

We find that the IASB has not consistently applied the definitions and recognition criteria for assets and liabilities from the CF. Our analysis does not show that these departures reflect a new and commonly accepted principle that is meant to be applied on a consistent basis in future standard setting. The departures have resulted in a variety of standards that prohibit recognition of items that meet the definition of an asset or a liability, standards that require the recognition of assets and liabilities that do not meet the definitions, and standards that have inconsistent requirements for similar assets and liabilities. Our analysis shows that those existing standards that require recognition of assets or liabilities for which an inflow or outflow of economic benefits is not probable would be brought into line with the DP's revised definitions. When existing standards prohibit the recognition of items that would meet the new (and in various cases also existing) definitions, not recognising these assets or liabilities could potentially be justified based on the relevance and faithful representation criteria laid out in the DP. If the IASB decision making in the past has been driven by these criteria, the DP would align the recognition criteria to the thinking that underlies existing standards, but this cannot be properly assessed because the Bases for Conclusions for most standards are silent about such considerations. The DP furthermore provides no further clarity on the new CF's impact on items that have the nature of deferred cost or income rather than meeting the definitions of an asset or a liability.

Our analysis, the IASB's ongoing standard setting activities and its response to comments received on the DP (IASB 2014a), suggests that in relation to the recognition of assets and liabilities, the DP does not significantly assist in developing a new and robust framework for consistent standard setting. Standard setting will therefore continue to be the outcome of a political debate in which stakeholders will justify and defend their proposals based on arguments that find their foundation in the subjective criteria around relevance and faithful representation. This is not necessarily bad. As noted by Gerboth (1987), relevant standards can be developed without pre-agreed consistent definitions and principles, based on a sophisticated debate between well-educated professionals. However, it is doubtful whether the new CF will meet the objective of being a solid basis for the consistent development of accounting standards, providing clear guidance in addressing controversial matters such as leases, rate-regulated activities, intangible assets and non-financial liabilities.

We end this paper with four recommendations for the IASB in relation to the development and use of the CF. First, we believe that our analysis reveals a need to provide clarity about the extent to which, and under what conditions, cost and income deferrals fit into the objectives of financial reporting and meet the definitions of assets and liabilities. Second, the evaluation and discussion of judgemental criteria related to relevance and faithful representation are an important factor in developing recognition requirements in the standards. Therefore, it is crucial that a due process is followed, diligently weighing all the inputs and views about those criteria, to arrive at standards. The Basis for Conclusions to each standard should explain in detail how the IASB has evaluated the $\mathrm{CF}$ recognition criteria in relation to relevance and faithful representation. This would include an evaluation of the counterarguments as well as an analysis of the conclusions in relation to those reached for similar assets and liabilities in other standards. Third, the IASB should ensure that 
there is less need for entities to refer to judgemental criteria, when making decisions about the recognition of assets or liabilities, by developing a generic standard (or a separate section in the $\mathrm{CF}$ ) containing recognition criteria for assets and liabilities that are not dealt with in any other standard. Finally, our analysis shows that a CF should be treated as a living document. The thinking about the concepts underlying financial reporting changes over time and new questions are raised to the IASB. New standard-setting activities and debates as part of those standardsetting activities may shed new light on those concepts. Continuous re-assessment of the CF, rather than once every 25 years, in combination with improved information in the Bases for Conclusions to the individual standards would provide clarity about the IASB's motivations for standard-setting decisions and about whether deviations from the then current CF are to be considered a one-time exception or a reflection of changed thinking.

\section{Acknowledgements}

We appreciate useful comments by Mary Barth, Ralph ter Hoeven, Rachel Knubley, Christopher Nobes, Ann Tarca, Leo van der Tas, Jeffrey Wilks, two anonymous reviewers and participants of the IASB Research Forum at the Saïd Business School, University of Oxford, on 2 October 2014.

\section{Disclosure statement}

No potential conflict of interest was reported by the authors.

\section{Notes}

1. Although the DP and the standards refer to the statement of financial position, IAS 1 Presentation of Financial Statements (para. 10) specifically allows other titles to be used.

2. Refer to www.ifrs.org/Current-Projects/IASB-Projects/Liabilities/Pages/Liabilities.aspx.

3. Refer to www.ifrs.org/Current-Projects/IASB-Projects/Leases/Pages/Leases.aspx.

4. See www.ifrs.org/Current-Projects/IFRIC-Projects/Documents/IFRIC-items-not-taken-onto-the-agenda -IAS-1-41.pdf.

5. Refer to www.ifrs.org/Current-Projects/IASB-Projects/Revenue-Recognition/Pages/Board-discussions5.aspx.

6. See www.ifrs.org/Current-Projects/IFRIC-Projects/Documents/IFRIC-items-not-taken-onto-the-agenda -IAS-1-41.pdf.

7. See www.ifrs.org/Current-Projects/IFRIC-Projects/Documents/IFRIC-items-not-taken-onto-the-agenda -IAS-1-41.pdf.

\section{References}

Aboody, D. and Lev, B., 1998. The value relevance of intangibles: the case of software capitalization. Journal of Accounting Research, 36 (Suppl.), 161-191.

Amir, E., Kirschenheiter, M.T., and Willard, K.L., 1997. The valuation of deferred taxes. Contemporary Accounting Research, 14 (4), 597-622.

Amir, E. and Sougiannis, T., 1999. Analysts' interpretation and investors' valuation of tax carryforwards. Contemporary Accounting Research, 16 (1), 1-33.

Ayers, B., 1998. Deferred tax accounting under SFAS No. 109: an empirical investigation of its incremental value-relevance relative to APB No. 11. Accounting Review, 73 (4), 195-212.

Barker, R. and McGeachin, A., 2013. Why is there inconsistency in accounting for liabilities in IFRS? An analysis of recognition, measurement, estimation and conservatism. Accounting and Business Research, 43 (6), 579-604.

Barth, M.E., Clement, M.B., Foster, G., and Kasznik, R., 1998. Brand values and capital market valuation. Review of Accounting Studies, 3 (1-2), 41-68.

Barton, A.D., 1970. Company income tax and inter-period allocation. Abacus, 6 (1), 3-24. 
Beaver, W.H., 1991. Problems and paradoxes in the financial reporting of future events. Accounting Horizons, December, 5 (4), 122-134.

Bloom, M., 2009. Accounting for goodwill. Abacus, 45 (3), 379-389.

Booth, B., 2003. The conceptual frameowrk as a coherent system for the development of accounting standards. Abacus, 39 (3), 310-324.

Bradbury, M.E., 2003. Implications for the conceptual framework arising from accounting. Abacus, 39 (3), $388-397$.

Buckley, J.W., 1972. Income Tax Allocation: An Inquiry into Problems of Methodology and Estimation. New York: Financial Executives Research Foundation.

Chambers, R.J., 1968. Tax allocation and financial reporting. Abacus, 4 (2), 99-123.

Chambers, R.J., 1996. Ends, ways, means and conceptual frameworks. Abacus, 32 (2), 119-132.

Chludek, A., 2011. Perceived versus actual cash flow implications of deferred taxes: an analysis of value relevance and reversal under IFRS. Journal of International Accounting Research, 10 (1), 1-25.

Cortese-Danile, T.M. and Gornik-Tomaszewski, S., 2002. Setting new standards for business combinations and intangible sssets. Review of Business, 23 (1), 10-15.

Dean, G.W. and Clarke, F.L., 2003. An evolving conceptual framework? Abacus, 39 (3), 279-297.

Dichev, I.L., 2008. On the balance sheet-based model of financial reporting. Accounting Horizons, 22 (4), $453-470$.

Eckstein, C., 2004. The measurement and recognition of intangible assets: then and now. Accounting Forum, 28 (2), 139-158.

FRC, 2014. A Review of the Conceptual Framework for Financial Reporting (DP/2103/1) - FRC Reponse. London: Financial Reporting Council.

Gerboth, D.L., 1987. The conceptual framework: not definitions but professional values. Accounting Horizons, 1 (3), 1-8.

Gordon, E.A. and Joos, P.R., 2004. Unrecognized deferred taxes: evidence from the U.K. Accounting Review, 79 (1), 97-124.

Guenther, D.A. and Sansing, R.C., 2000. Valuation of the firm in the presence of temporary book-tax differences: The role of deferred tax assets and liabilities. Accounting Review, 75 (1), 1-12.

Hellman, N., 2008. Accounting conservatism under IFRS. Accounting in Europe, 5 (2), 71-100.

Hines, R.D., 1989. Financial accounting knowledge, conceptual framework projects and the social construction of the accounting profession. Accounting, Auditing \& Accountability Journal, 2 (2), 72-92.

Hines, R.D., 1991. The FASB's conceptual framework, financial accounting and the maintenance of the social world. Accounting, Organizations and Society, 16 (4), 313-331.

IASB, 2009. Discussion Paper: Leases Preliminary Views. London: IASB.

IASB, 2010a. Exposure Draft ED/2010/9 Leases. London: International Accounting Standards Board.

IASB, 2010b. Staff Paper: Recognising Liabilities Arising from Lawsuits. London: International Accounting Standards Board.

IASB, 2010c. Conceptual Framework for Financial Reporting 2010. London: International Accounting Standards Board.

IASB, 2012. Feedback Statement: Agenda Consultation 2011. London: International Accounting Standards Board.

IASB, 2013a. Discussion Paper: A Review of the Conceptual Framework for Financial Reporting. London: International Accounting Standards Board.

IASB, 2013b. Exposure Draft ED/2013/6 Leases. London: International Accounting Standards Board.

IASB, 2014a. Staff Paper: Effect of Board Redeliberations on DP: A Review of the Conceptual Framework for Financial Reporting. London: International Accounting Standards Board.

IASB, 2014b. IFRS 15 Revenue from Contracts with Customers. London: International Accounting Standards Board.

IASC, 1989. Framework for the Preparation and Presentation of Financial Statements. London: International Accounting Standards Committee.

IFRS IC, 2013. IFRIC 21 Levies. London: IFRS Interpretations Committee.

Jones, S. and Wolinzer, P.W., 2003. Harmonization and the conceptual framework: an international perspective. Abacus, 3 (3), 375-387.

Kallapur, S. and Kwan, S.Y.S., 2004. The value relevance and reliability of brand assets recognized by U.K. firms. Accounting Review, 79 (1), 151-172.

Laux, R.C., 2013. The association between deferred tax assets and liabilities and future tax payments. Accounting Review, 88 (4), 1357-1383. 
Lev, B., 2003. Remarks on the measurement, valuation, and reporting of intangible assets. Economic Policy Review, 9 (3), 17-22.

Lev, B. and Sougiannis, T., 1996. The capitalization, amortization and value-relevance of R\&D. Journal of Accounting and Economics, 21 (1), 107-138.

Loftus, J.A., 2003. The CF and accounting standards: the persistence of discrepancies. Abacus, 39 (3), 298-309.

Ma, R. and Hopkins, R., 1988. Goodwill - an example of puzzle-solving in accounting. Abacus, 24 (1), $75-85$.

McGregor, W. and Street, D.L., 2007. IASB and FASB face challenges in pursuit of joint conceptual framework. Journal of International Financial Management and Accounting, 18 (1), 39-51.

Mohd, E., 2005. Accounting for software development costs and information assymetry. Accounting Review, $80(4), 1211-1231$.

Murray, D., 2010. What are the essential feautures of a liability? Accounting Horizons, 24 (4), 623-633.

Newberry, S., 2003. Reporting performance: comprehensive income and its components. Abacus, 39 (3), $325-339$.

O'Brien, P., 2009. Changing the concepts to justify the standards. Accounting Perspectives, 8 (4), 263-275.

Peasnell, K.V., 1982. The function of a conceptual framework for corporate financial reporting. Accounting and Business Research, 12 (48), 243-256.

Penman, S.H., 2009. Accounting for intangible assets: there is also an income statement. Abacus, 45 (3), $358-371$.

Rees, H., 2006. The IASB's proposed amendments to IAS 37. Accounting in Europe, 3 (1), 27-34.

Samuelson, R.A., 1993. Accounting for liabilities to perform services. Accounting Horizons, 7 (3), 32-45.

Samuelson, R.A., 1996. The concept of assets in accounting theory. Accounting Horizons, 10 (3), 147-157.

Schmidt, M., 2013. Equity and liabilities - a discussion of IAS 32 and a critique of the classification. Accounting in Europe, 10 (2), 201-222.

Solomons, D., 1986. The FASB's conceptual framework: an evaluation. Journal of Accountancy, June, 114124.

Walker, R.G., 2003. Objectives of financial reporting. Abacus, 39 (3), 340-355.

Walker, R.G. and Oliver, G.R., 2005. Accounting for expenditure on software development for internal use. Abacus, 41 (1), 66-91.

Watts, R.L. and Zimmerman, J.L., 1979. The demand for and supply of accounting theories: the market for excuses. Accounting Review, 54 (2), 273-305.

Whittington, G., 2008. Harmonisation or discord? The critical role of the IASB conceptual framework review. Journal of Accounting and Public Policy, 29 (6), 495-202.

Wyatt, A., 2005. Accounting recognition of intangible assets: theory and evidence on economic determinants. Accounting Review, 80 (3), 967-1003.

Zeff, S.A., 2002. "Political" lobbying on proposed standards: a challenge to the IASB. Accounting Horizons, $16(1), 43-54$. 